\title{
Development of Adrenal Glands from the Embryonic Phase to Puberty in Spix's Yellow-toothed Cavies (Galea spixii, Wagler, 1831)
}

\author{
Luis Miguel Lobo ${ }^{1 *}$, Amílton Cesar dos Santos¹, Moacir Franco de Oliveira², Antônio \\ Chaves Assis-Neto ${ }^{1}$ \\ ${ }^{1}$ School of Veterinary Medicine and Animal Science, University of São Paulo - Surgery Department - São Paulo, \\ São Paulo Brazil; ${ }^{2}$ Federal Rural University of Semiarid - Animal Science Mossoró, Rio Grande do Norte Brazil
}

\begin{abstract}
Several authors have underscored the importance of establishing parameters in morphological development by gender comparison to establish clinical and pre-clinical assays through the use of experimental models. Current research compares the morphometry of right and left adrenal glands of males and females and describes differentiation of the cortex and medulla tissue during the embryonic, pre-puberty and puberty phases in Spix's yellow-toothed cavies. Embryos aged 22 (22D), 25 (25D), 30 (30D), 40 (44D) and >50 (50D) days of gestation and neonates aged 15 (15DPN) (DPN= Days postnatal), 30 (30DPN) and $90(90 D P N)$ days after birth were analyzed. Comparisons included morphometric and histological analysis in all periods described. When compared the right and left adrenal glands, results show that the length and width have statistical differences $(p<0.05)$. Statistical difference between right and left glans for weight occurred only after 30D in males and after 50D in females. When compared male and females, no statistical difference in the right and left glands was extant. In the case of tissue differences, the glomerular zone is the first to emerge after 22D, followed by the fasciculate zone after 25D and by the reticular zone during the post-natal period. Medullar tissue was spread between the cortical tissue at the onset of development, establishing itself at the center of the organ since the end of pregnancy (>50D) up to puberty. Considering tissue differentiation, there was no difference between the adrenal glands of male and female cavies or between the right and left adrenal glands.
\end{abstract}

Keywords: Adrenal córtex; Cavidae; experimental model; Rodentia; steroidogenesis

\footnotetext{
*Author for correspondence: miguellobo@usp.br
} 


\section{INTRODUCTION}

Spix's Yellow Toothed (SYT) cavies (Galea spixii, Wagler, 1831) are hystricomorphic rodents weighing approximately $375-405 \mathrm{~g}$ and measuring approximately $30-35 \mathrm{~cm}$ in their adult phase. They belong to the family Caviidae and are distributed in the vegetation of the semi-arid region of northeastern Brazil ${ }^{[1-2]}$. In Brazil, SYT cavies are bred in captivity as alternative food source, for the preservation of the species and as animal research models ${ }^{[1-3-4-5]}$. Females have a short pregnancy period ( \pm 50 days $)$, with 2 to 4 litters. The male's onset of puberty occurs around 45 days postnatal (DPN) ${ }^{[6]}$; the female becomes pregnant even when nutritional conditions are unfavorable ${ }^{[7]}$.

Streamline research on adult male and female SYT cavies has shown that their adrenal glands are asymmetric, with different shapes, and their left adrenal gland is greater than the right one. Although cortex zones are histologically similar, there seems to be a higher concentration of the substrate (lipid drops) for the production of steroid hormones in the fascicular zone, expressing enzyme cytochrome P50c17, involved in the production of androgen hormones ${ }^{[4]}$.

Adrenal glands in mammals, including adult SYT cavies ${ }^{[4]}$, are pair organs composed of two distinct regions, namely, the cortex, originating from the mesoderm, and the medulla, originating from the neuroctoderm. The cortex of adult animals is divided into three distinct regions organized from the most external to the most internal, featuring the glomerular zone, fasciculate zone and reticular zone, respectively ${ }^{[8]}$. The gland's different regions produce different hormones. Mineralocorticoids, glucocorticoids and sexual hormones are produced in the cortex, whereas adrenalin and noradrenalin are mainly produced by the medulla ${ }^{[4-8-9]}$.

Through different hormones, adrenal glands have an important role in homeostasis and in birth-inducing mechanisms ${ }^{[10]}$. However, morphological information is lacking on ontogeny and tissue differentiation of the adrenal gland, which is required for fetal maturity, preparation for birth and neonatal survival. Further, several authors have recently debated on the relevance of establishing development parameters through gender comparison since most clinical and pre-clinical assays involve tests without taking into account the gender of the experimental model ${ }^{[1-12-13]}$.

Foregrounded on the relevance of SYT cavies as experimental models, current research morphometrically compares the right and left adrenal glands of males and females and describes the cortex and medulla differentiating tissue during the embryonic, fetal, prepuberty and puberty phases of SYT cavies. Morphological details are provided for indepth studies with regard to the different sites of production and physiological mechanisms of different hormones produced in the gland by males and females.

\section{MATERIALS AND METHODS}

\section{Animals: Origin and Conditioning}

Current study used 24 adult female and 8 male SYT cavies (between 3 and 9 months old) to obtain embryos, fetuses and post-natal animals. Animals were divided into three $2.5 \mathrm{~m}^{2} \times 2 \mathrm{~m}$ high boxes with 3 females and one male. The boxes were surrounded by a wire net and covered by asbestos roofing; dry leaves covered the floor for nest building. Animals were provided with fruits, rabbit diet and water ad libitum.

All the cavies originated from the Center for the Multiplying of Wild Animals of the Universidade Federal Rural do Semiárido in Mossoró RN Brazil, licensed by IBAMA 2028236/2008 and by the bioethic committee of the School of Veterinary Medicine and Animal Science of the Universidade de São Paulo/Campus São Paulo, by protocol 2923/2013. Protocol 41552-1 for the collection and transport of wild animals of the 
Brazilian fauna was conceded by the Ministry of the Environment (MMA), Chico Mendes Institute for the Conservation of Biodiversity (ICMBio), Authorization and Information in Biodiversity System (SISBIO).

\section{Mating Detection and the Retrieval of Adrenal Glands}

Females were identified individually so that they could be analyzed on a daily basis for the detection of copula through spermatozoids on vaginal swabs and analyzed by the exfoliative vaginal cytology method ${ }^{[14]}$. When copula was detected, the females were separated and placed in other boxes for the required pregnancy period. Pregnant cavies were first anaesthetized with xylazine hydrochloride $(4 \mathrm{mg} / \mathrm{kg} / \mathrm{IM})$ and ketamine hydrochloride $(60 \mathrm{mg} / \mathrm{kg} / \mathrm{IM})$ and euthanized with sodium thiopental $2.5 \%$ $(60 \mathrm{mg} / \mathrm{Kg} / \mathrm{IC})$ by intracardiac injection.

After euthanasia, the fetuses were retrieved by dissecting the cavy females by an incision on the alba line and aperture of the abdominal cavity. The uteruses were extracted and the embryos and fetuses removed. In the case of pre-puberty and puberty animals, age was counted as from the day of birth and the same euthanasia method was employed. The gender of embryos, fetuses, pre-puberty and puberty animals were identified by external genitals. They were then dissected; the adrenal glands were removed and measured on a digital scale and by a precision digital caliper. The glands were then submerged in a solution of formaldehyde $10 \%$.

Embryos and fetus aged 22 (22D), 25 (25D), 30 (30D), 40 (40D) and >50 (term-to-term) (>50D) days of pregnancy were used, taking into consideration the species's pregnancy period of 45-50 days ${ }^{[1]}$; neonates at $15(15 \mathrm{DPN})(\mathrm{DPN}=$ Days postnatal) and 30 days (pre-puberty) (30DPN) and after 90 days (puberty) (90DPN), taking into consideration that puberty occurs after 45 days of birth ${ }^{[5]}$.

\section{Morphometric Analysis}

Measurements for weight (grams $=\mathrm{g}$ ), length between cranial and caudal extremity (millimeters $=\mathrm{mm}$ ) and width (millimeters $=\mathrm{mm}$ ) were taken for the morphometric comparison between right and left adrenal glands. Right and left adrenal glands were compared; later, the right and left glands of males and females were compared.

The analysis of variance with GraphPad InStat program was performed to obtain mean and standard deviation. Cramer-von Mises test for normality was employed to check homoscedasticity between variables; Tukey's comparison average test provided morphometric rates. Biometric variables are unstable $(\mathrm{CV} \leq 15 \%)$ at significance concentration $\mathrm{p}<0.05$.

\section{Processing of the Material for Observations under Light Microscope}

Samples of the right and left adrenal glands were retrieved from sexually undifferentiated 22D-old embryos and from both genders at all ages described above. Samples were fixed in formaldehyde and then dehydrated in a series of increasing ethanol concentrations (60\% to 100\%) and diaphanized in xylol to be later included in paraffin. Further, $5 \mu \mathrm{m}$ thick paraffin blocks were cut by microtome Leica RM 2155 and stained in HE Hematoxylin/Eosin (HE). Laminas were mounted with Entelan and slides for the observation of cell morphology. Microscope photo-documentation was made by Olympus Photomicroscope BX61VS. 


\section{RESULTS}

\section{Morphometric Analyses}

Morphometric analysis provided data on weight, length and width of the adrenal glands. Figure 1 shows graphs with data on weight, length and width of pre-natal and post-natal adrenal glands.

Significant differences $(\mathrm{p}<0.05)$ in weight were reported between the left (bigger) and the right (smaller) adrenal gland after 50D (Fig. 1A) in females and after 30D in males (Fig. 1B). There were significant differences in length and width at all periods for all the groups (Fig. 1C-F). There was no significant difference between males and females when the right and left glands were compared $(p>0.05)$ for any of the variables analyzed.

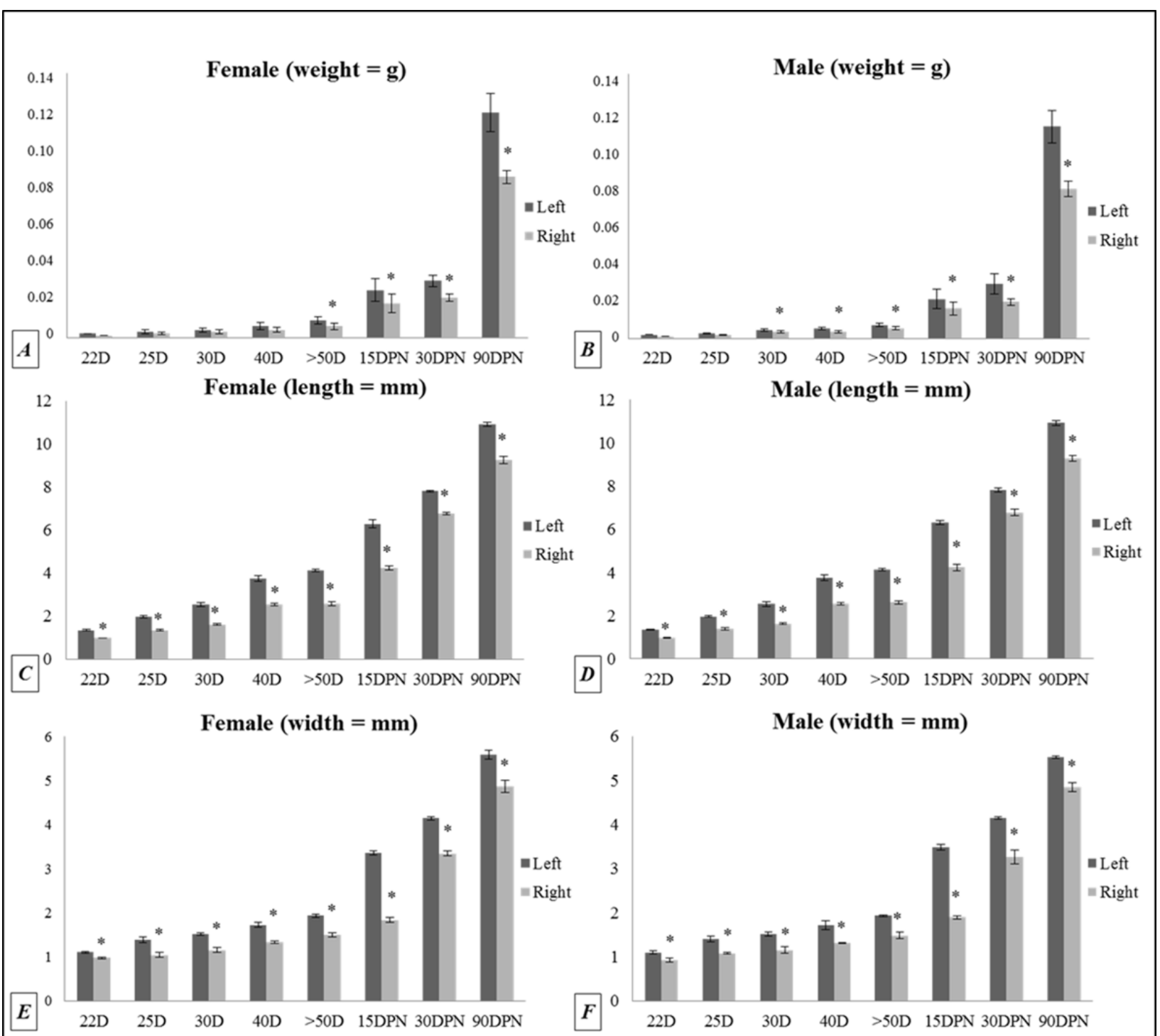

Figure 1. Morphometry of right and left adrenal glands of SYT cavies. * statistical difference $(p<0.05)$ by Tukey's test. 


\section{Anatomic and Topographic Aspects}

Topographic parameters revealed adrenal glands of the right and left antimeres related in a cranial-medial way to the right and left kidney respectively. Further, the right adrenal glands tended more to the cranial side when compared to the left adrenal glands (Fig. 2A-C). The right adrenal glands were related ventral-caudally to the liver, whereas the left adrenal glands were related ventral-caudally to the stomach at all ages of pregnancy. Moreover, the right adrenal glands had a more irregular shape than the left ones, or rather, the right adrenal glands had a pyramidal shape whereas the left ones had an elongated one.

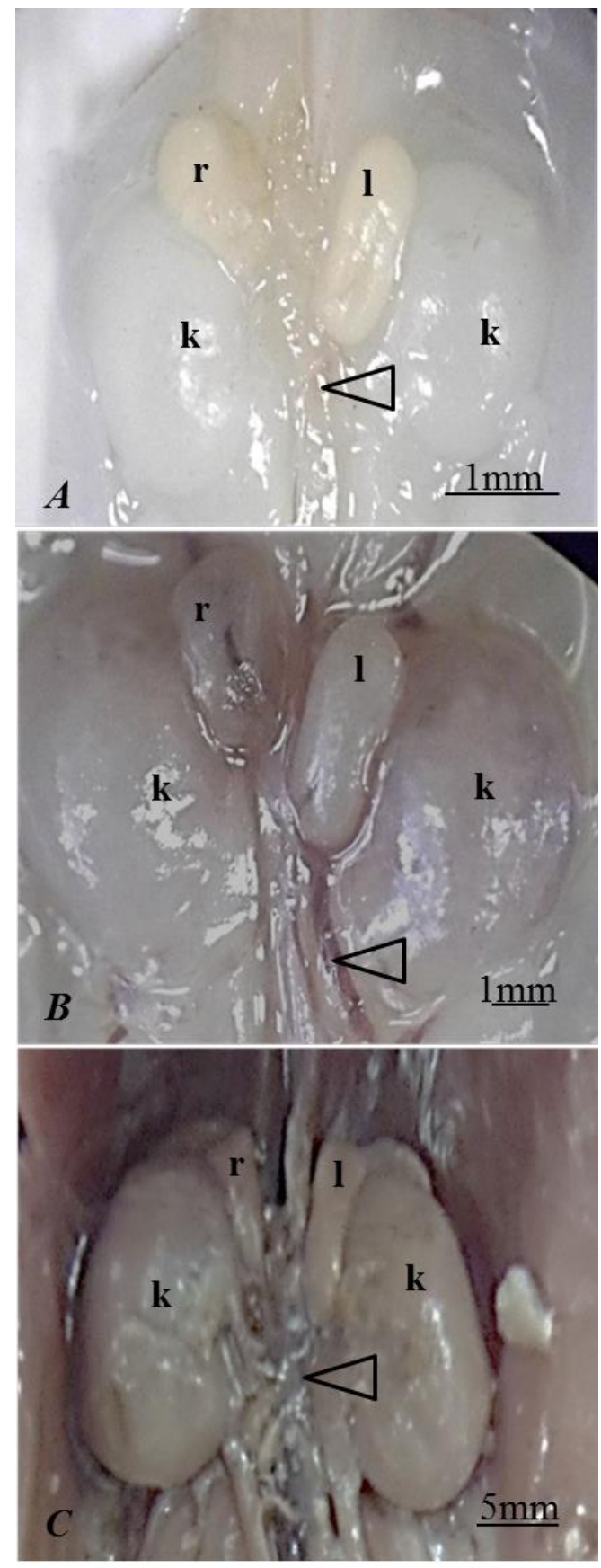

Figure 2. Topography of the left (l) and right (r) adrenal glands. Note that glands lie on the cranial poles of the kidneys (k) and are related to caudal vena cava (arrowhead). A: 22D; B: >50D; C, 90DPN. 


\section{Light Microscopy}

Light microscopy revealed tissue differentiation pattern between the cortical and medullar tissue from the embryo period to puberty. In current study, the adrenal glands at all pregnancy ages were provided with medullar and cortical tissues, although glands did not show all the differentiated zones of the cortex during the pre-natal period. The cortex differentiation in glomerular, fasciculate and reticular zones was reported during the post-natal period, but more evident during puberty.

The right and left glands of both genders of SYT cavies at 22D had agglomerates of chromaffin cells spread between the blood vessels and the cortical tissue. Sections of the cortical tissue of the glomerular zone were positioned at the margin, arranged in ovoid groups and below the organ's capsule formed by conjunctive tissue (Fig. 3A-B).

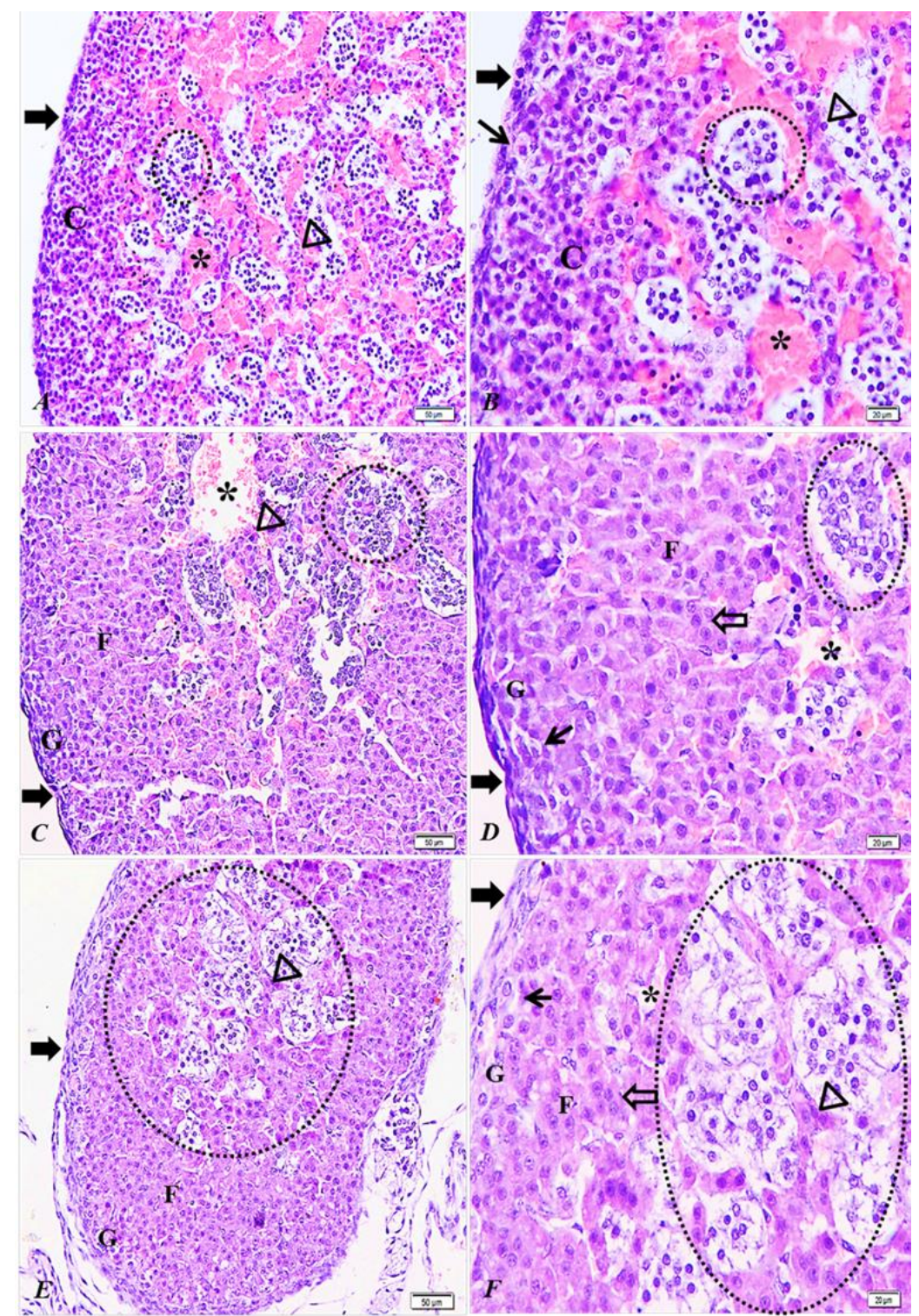

Figure 3. Photomicrography of adrenal glands of SYT cavies at 22D (A-B), 25D (C-D) and 30D (E-F). Cortical region $(\mathrm{C})$; glomerular zone $(\mathrm{G})$; fasciculate zone $(\mathrm{F})$; groups of ovoid cells of the glomerular zone (thin arrow) enveloped in capsule (arrow); cell cords of the fasciculate zone (striped arrow); medullar region with groups of chromaffin cells (circle) and blood vessels (*) between the cortical tissue (arrowhead). A, C, E: Bars = 50 $\mu \mathrm{m}$. B, D

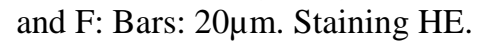


At 25D (Fig. 3C-D), 30D (Fig. 3E-F), 40D (Fig. 4A-B) and >50D (Fig. 4C-D), the right and left adrenal glands of both genders showed a differentiated cortex in the glomerular zone characterized by ovoid groups of cells enveloped by the organ's capsule, and the fasciculate zone composed of polyhedron cells arranged in cords. Agglomerates of medullar tissue composed of chromaffin cells separated by cortical tissue and several blood vessels were also registered. The medullar tissue remained more at the center of the organ as from 30D henceforth.

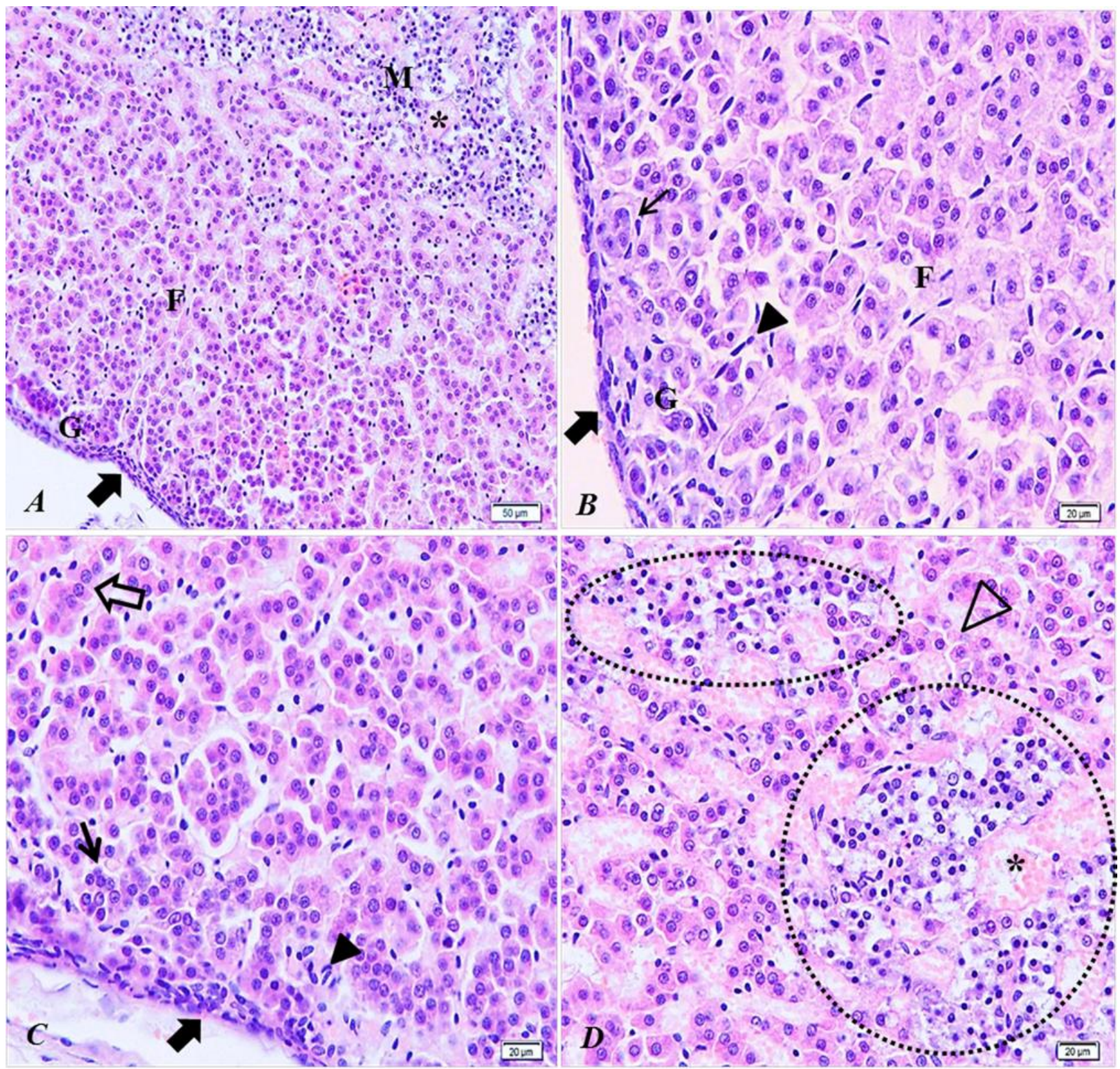

Figure 4. Photomicrographs of adrenal gland of SYT cavies at 40D (A, B) and 50D (C-D). Glomerular zone (G); fasciculate zone (F); medullar zone (M); ovoid groups of cells of the glomerular zone (thin arrow) enveloped by the capsule (arrow); cell cords of the fasciculate zone (striped arrow); fibroblastoid cells (black arrowhead) of fascicular zone; medullar region with groups of chromaffin cells (circle) and blood vessels (*) between the cortical tissue (arrowhead). A: Bar $=50 \mu \mathrm{m}$. B, C E D: Bars $=20 \mu \mathrm{m}$. Staining HE.

At 15DPN (Fig. 5A-B), 30DPN (Fig. 5C-D) and 90DPN (Fig. 5E-F), the adrenal glands revealed differences in the cortical tissue in the glomerular, fasciculate and reticular zones. The glomerular zone was the most external, lying below the organ's capsule; the 
fasciculate zone lay in the center, between the glomerular and reticular zones; the inner reticular zone touched the medulla. The pyramidal cells in the glomerular zone were spread in irregular ovoid groups, while the polyhedron cells of the fascicular zone formed radial cords and the reticular zone was composed of anastomosed cell cords forming an irregular network separated by sinusoid capillaries.

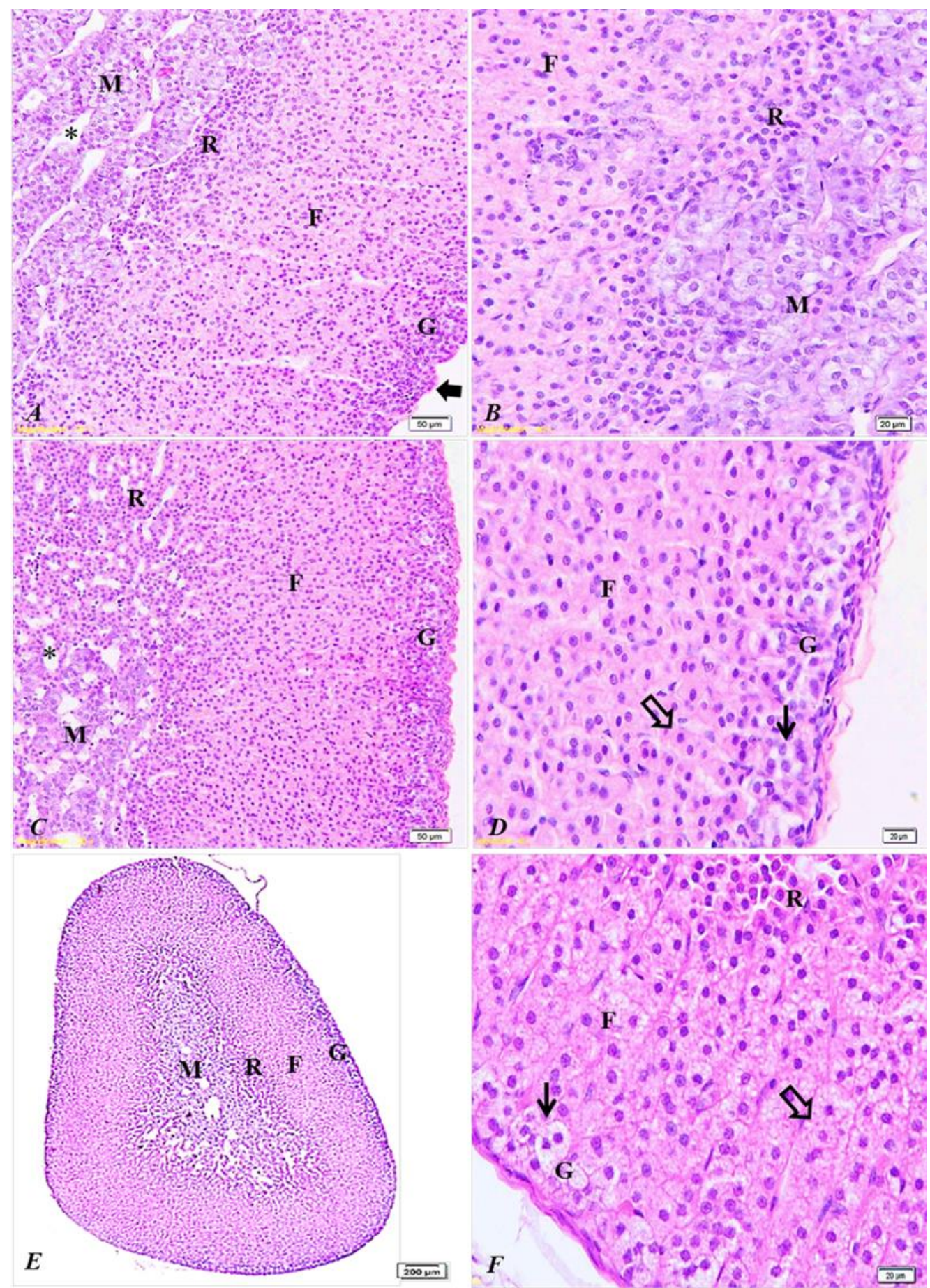

Figure 5. Photomicrographs of the adrenal glands of SYT cavies at 15DPN (A, B), 30DPN (C-D) and 90 DPN (E-F). Glomerular zone $(\mathrm{G})$; fascicular zone $(\mathrm{F})$; reticular zone $(\mathrm{R})$; medullar region $(\mathrm{M})$; ovoid group of cells of the glomerular zone (thin arrow) enveloped by the capsule (arrow); cell cords of the fascicular zone (striped arrow); medullar region with groups of chromaffin cells (circle) and blood vessels $(*)$ between the cortical tissue (arrowhead). A, C, E: Bar $=50 \mu \mathrm{m}$. B, D and F: Bar $=20 \mu \mathrm{m}$. Staining HE. 


\section{DISCUSSION}

Several researchers have discussed the importance of establishing more precise parameters for morphological development, especially on the development of genders to improve clinical and pre-clinical assays with experimental models ${ }^{[11-12-13]}$. Current analysis detailed the morphological development of the adrenal glands of SYT cavies from the embryo phase to puberty. Data are important since SYT cavies have been used as experimental models for embryonic studies ${ }^{[1-15]}$, studies on reproduction physiology $y^{[5-16]}$ and on the morphology and adrenal steroidogenesis in adult animals ${ }^{[4]}$. Current analysis revealed topographic asymmetry between the adrenal glands, or rather, the right gland lying cranially towards the left. The same results have also been described for adult SYT cavies ${ }^{[4]}$ and other wild rodents, such as the plains vizcacha (Lagostomus maximus) $^{[17]}$, coypu (Myocastor coypus) ${ }^{[18-19]}$, agouti (Dasyprocta aguti $^{[20]}$, guinea pigs (Cavia porcellus) $)^{[21]}$ and humans ${ }^{[22]}$.

Moreover, adrenal glands have irregular shapes: the left glands have an elongated shape, whereas the right ones are conical or pyramidal, as also described for adult SYT cavies $^{[4]}$, Cavia porcellus $^{[21]}$ and Lagostamus maximus ${ }^{[17]}$. No difference between males and females has been reported on topographic data and on the glands' anatomic shape. Current analysis has also shown that the left gland has greater morphometric extensions than those of the right one. This has been proved by significant statistical differences $(p<0.05)$ among the groups under analysis. However, the weight of the adrenal glands is significantly different after 30D in males and after 50D in females. After these periods, significant difference occurred in all the others. There was no significant statistical difference ( $p>0.05)$ between the right and left glands when compared males and females. Results have been demonstrated in adult SYT cavies ${ }^{[4]}$, with morphometric differences between the right and left gland. Current analysis does not show any significant difference between males and females.

At 22D, the microstructure of the adrenal gland has a small region with cells arranged in ovoid groups which are characteristics of the cortex's glomerular zone. Groups of chromaffin cells were spread among the cortical tissue, with no well-defined medulla at this phase. After 25D, the fasciculate zone with cell cords emerged. Up till the end of pregnancy one may observe the adrenal gland of males and females divided into glomerular and fasciculate zones of the cortex and the agglomerates of the medullar tissue dispersed among the cortical tissue. The reticular zone only appeared at 15DPN. Quinn et al ${ }^{[8]}$ describe the ontogeny of the adrenal gland of the spiny mouse and showed that the cortex and the medulla only differentiated after 38 days of pregnancy, even though the differentiation of the cortex into three zones was visible only after eight days after birth.

In the case of the cortex's tissue differentiation, it may be suggested that the cells of the same cortical zone may produce different classes of hormones during pregnancy. Saadi and Lebaili ${ }^{[23]}$ suggest that changes in the cortex reflect the anatomical and physiological adaptive capacity of the adrenal gland to stress factors, by changing demand of several adrenal hormones. Glucocorticoids are classified as mediators within the process of the onset of birth and thus required during intrauterine development ${ }^{[9]}$. Sexual hormones produced by the adrenal glands may participate in the processes involving sexual dimorphism ${ }^{[24]}$. On the other hand, mineralocorticoids affect the electrolytic equilibrium ${ }^{[23]}$. In fact, adrenal hormones are relevant for the organism's homeostasis.

The knowledge on normal development of the adrenal glands is relevant due to the secreted hormones required for the regulation of intra-uterine homeostasis and for the differentiation and maturity of the fetal organs. These hormones have a highly complex 
role during the fetus's life and they may be the basis of cell communication that coordinates mother-fetus interactions while modulating the functional adaptability for extra-uterine life during the perinatal period ${ }^{[25-26]}$. Early studies ${ }^{[27]}$ have demonstrated sexual differentiation in SYT cavies and possible masculinization in female genital organs. From present data, synthesis of sexual hormones in the adrenal glands of fetuses may be studied in order to explain possible participation of adrenal hormones in this proccess.

Further, adrenal glands may differ in morphology, anatomy and secretion products among the different zoological classes and species. Chromaffin and adrenal-cortical tissues in fish are often separated, revealing the medullar tissue spread in agglomerates within the cortical tissue. The adrenal cortex of mammals is divided into zones, although the glomerular zone may not be visible in some animals such as lemurs, mice and monkeys. The adrenal-cortical tissues of dogs and guinea pigs are much more abundant than the chromaffin tissue ${ }^{[28-29]}$. The adrenal gland's morphological variation among the species is related to structural changes as an adaptation to stress response. Ultrastructural alterations in the gland have been associated to environmental stress responses ${ }^{[30-31]}$. Studies have focused on nuclear imaging techniques to detect response of the hypothalamus-pituitary-adrenal axis during the stress ${ }^{[32]}$. Another study demonstrated that the adrenal glands of the gerbil (Gerbillus tarabuli) had a decrease in cholesterol drops in the cells due to an increase in the production of aldosterone by water-rich diet and to decrease metabolism and adjustments in the concentration of electrolytes. The above suggests that the glomerular zone actively participates in the development of strategies for anatomic and physiological adaptations ${ }^{[23]}$.

In brief, adrenal glands proved to have statistical differences $(p<0.05)$ when length and width of the right and left glands are compared. However, statistical differences in weight only occurred after 30D in males and 50D in females, up to puberty. There was no statistical difference between the glands comparing males and females. Further, the glomerular zone is the first in emergence at 22D, followed by the fasciculate zone at $25 \mathrm{D}$ and the reticular zone during the post-natal phase. The medullar tissue is dispersed between the cortical tissue at the onset of development, followed by its establishment in the organ's center since the end of pregnancy (>50D) up to puberty. Histological differences between the male's and female's adrenal gland or between the right and left glands have not been reported in current analysis.

\section{ACKNOWLEDGEMENTS}

To the Federal Rural University of the Semi-Arid for donating the animals used in research and to Fundação de Amparo à Pesquisa do Estado de São Paulo (FAPESP) for financial support.

\section{REFERENCES}

1. Oliveira MF, Mess A, Ambrósio CE, Dantas CAG, Favaron PO, Miglino MA. Chorioallantoic Placentation in Galea Spixii (Rodentia, Caviomorpha, Caviidae). Reprod Biol Endocrinol. 2008; 6(39): 1-8.

2. Adrian O, Sachser N Diversity of social and mating systems in cavies: a review. J Mammal. 2011; 92(1): 39-53.

3. Santos AC, Oliveira GB, Viana DC, Oliveira FD, Silva RS, Rici REG, et al. Development and morphological changes in the vaginal closure membrane throughout gestation in Galea spixii (Rodentia: Caviidae). Microsc Res Tech. 2016a; 79(5): 359-364.

4. Santos AC, Viana DC, Bertassoli BM, Vasconcelos BG, Oliveira DM, Rici REG, et al. Adrenal glands of Spix's yellow-toothed cavy (Galea spixii, Wagler, 1831): morphological and morphometric aspects. Braz J Biol. 2016b; 76(3): 645-655. 
5. Oliveira GB, Rodrigues MS, Sousa ES, Albuquerque JFG, Moura CEB, Ambrósio CE, et al. Origem e distribuição dos nervos isquiáticos do preá. Ciência Rural. 2010; 40(8): 1741-1745. 6. Santos PR, Oliveira MF, Silva AR, Assis-Neto AC. Development of spermatogenesis in captive-bred Spix's yellow-toothed cavy (Galea spixii). Reprod Fertil Develop. 2012; 24(4): 877-885.

7. Larcher-Jr TE. The comparative social behaviour of Kerodon rupestris and Galea spixii and the evolution of behaviour in the Caviidae. Bull Carnagie Mus Nat Hist. 1981; 17(1): 1-71. 8. Quinn TA, Ratnayake U, Dickinson H, Nguyen T, Mcintosh M, Castillo-Melendez M, et al. Ontogeny of the adrenal gland in the spiny mouse, with particular reference to production of the steroids cortisol and dehydroepiandrosterone. Endocrinology. 2013; 154(3): 1190-1201.

9. Parker CR, Staton B, Grilliot M. Ontogeny of cytochrome B-5 andcytochrome P450C17 in the human fetal adrenal gland during normal development. Endocrinol Res. 2004; 30(4): 541542 .

10. Conley AJ, Assis-Neto AC. The ontogeny of fetal adrenal steroidogenesis as a prerequisite for the initiation of parturition. Exp Clin Endocrinol Diab. 2008; 116(7): 1-8.

11. Beery AK, Zucker I. Sex bias in neuroscience and biomedical research. Neurosc Biobehav Rev. 2011; 35(3): 565-572.

12. Woodruff TK, Kibbe MR, Paller AS, Turek FW, Woolley CS. Commentary: "Leaning in" to support sex differences in basic science and clinical research. Endocrinology. 2014; 155(4): 1181-1183.

13. Morselli E, Frank AP, Santos RS, Fátima LA, Palmer BF, Clegg DJ. Sex and Gender: Critical Variables in Pre-Clinical and Clinical Medical Research. Cell Metabolism. 2016; 24(8): 203-209.

14. Santos AC, Favaron PO, Viana DC, Silva FMO, Alcântara D, Vasconcelos B G, et al. Intrauterine development of female genital organs in Cavia porcellus (Rodentia, Caviidae). Pak J Zool. 2016c; 46(2): 389-397.

15. Oliveira MF, Vale AM, Favaron PO, Vasconcelos BG, Oliveira GB, Miglino MA, et al. Development of yolk sac inversion in Galea spixii and Cavia porcellus (Rodentia, Caviidae). Placenta. 2012; 33(10): 878-881.

16. Santos AC, Viana DC, Bertassoli BM, Oliveira GB, Oliveira DM, Oliveira MF, et al. Characterization of the estrous cycle in Galea spixii (Wagler, 1831). Pesq Vet Bras. 2015; 35(1): 89-94.

17. Ribes AC, Mohamed F, Dominguez S, Delgado M., Scardapane L, Guzman J, et al. Probable effect of photoperiod on seasonal variation in the nuclear volume of the adrenal cortex of viscacha (Lagostomus maximus maximus). Braz J Med Biol Res. 1999; 32(9): 1115-1120.

18. Machado GV, Romagnolli P, Souza JR., Turqueti VS, Uliana S M, Silva MH. Arterial supply for to the adrenal glands of the nutria (Myocastor coypus Molina, 1782). Arch Vet Sci. 2002; 7(2): 9-14.

19. Culau POV, Azambuja RC, Campos R. Collateral visceral branches of the abdominal aorta in Myocastor coypus (nutria). Acta Sci Vet. 2008; 36(3): 241-247.

20. Neves WC, Cavalcante-Filho MF, Carvalho MAM, Menezes DJ. A. Arteries of the adrenal glands in Golden cutia (Dasyprocta aguti, Rodentia). Rev FVZA. 2007; 14(2): 165-174.

21. Cooper G, Schiller AL. Anatomy of the Guinea pig. Harvard University Press: Cambridge; 1975.

22. Kempná P, Flück, CE. Adrenal gland development and defects. Best Pract Res Clin Endocrinol Metabol. 2008; 22(1): 77-93.

23. Saad L, Lebaili N. Effect of a water-rich diet on adrenal zona glomerulosa in Gerbillus tarabuli. Comptes Rendus Biol. 2012; 335(2): 96-102.

24. Lindeque M, Skinner JD, Millar RP. Adrenal and gonadal contribution to circulating androgens in spotted hyaenas (Crocruta crocruta) as revealed by LHRH, hCG and ACTH stimulation. J Reprod Fert. 1986; 78(1): 211-217.

25. Ju HY, Hong CR, Shin HY. Advancements in the treatment of pediatric acute leukemia and brain tumor - continuous efforts for 100\% cure. Korean J Pediat. 2014; 57(10): 425-430.

26. Santos AC, Viana DC, Oliveira GB, Lobo LM, Assis-Neto AC. Intrauterine Sexual Differentiation: Biosynthesis and action of Sexual Steroid Hormones. Braz Arch Biol Technol. 2015; 58(3): 395-405.

27. Santos AC, Conley AJ, Oliveira MF, Assis-Neto AC. Development of urogenital system in the Spix cavy: A model for studies on sexual differentiation. Differentiation. 2018; 101: 25-38. 
28. Bentley PJ. Comparative vertebrate endocrinology. 2ed. New York: Cambrigde University Press; 1982.

29. Kardong KV. Vertebrates: comparative anatomy, function, evoluction. 4ed. New York: McGraw-Hill; 2006.

30. Soldani P, Gesi M, Lenzi P, Natale G, Fornai F, Pellegrini A, et al. Long-term exposure to noise modifies rat adrenal cortex ultrastructure and corticosterone plasma levels. J Submicrosc Cytol Pathol. 1999; 31(3): 441-448.

31. Koko V, Djordjeviae J, Cvijiae G, Davidoviae V. Effect of acute heat stress on rat adrenal glands: a morphological and stereological study. J Exp Biol. 2004; 207(24): 4225-4230.

32. Cortez CM, Cruz, FAO, Silva, D. Psycological and physiological responses to stress: a review based on results from PET and MRI studies. Braz Arch Biol Technol. 2008; 51(spe): 7 12. 